\title{
THE CHURCH OF JESUS CHRIST OF LATTER-DAY SAINTS AND ITS DOCTRINE: A PHILOSOPHICAL APPROACH
}

\section{INTRODUCTION}

My research leads to a bit different view of the new religiosity so I am determined to begin with an explanation of how I examine this problematic, and why Mormons have become one of the objects of my interest.

\section{WHY PHILOSOPHY?}

What is important and helpful in understanding the methodological side of my research is that I am a philosopher of religion by education and profession. My department is a part of the Faculty of Philosophy. This is because of the view that I share, according to which to truly understand the phenomenon of new religious movements it is not enough to produce even the most detailed descriptions of how they function and what impact they have on individuals and societies. This is important, of course, but it all has to be accompanied, first, by reconstruction and analysis of the doctrines of those movements and then by a rational evaluation of the truth of its contents. These two constitute in fact the main goal of the entire research.

Of course, I am aware that expressing oneself in terms of trueness of a religious doctrine does not sit well with everyone. As a philosophicalrealist, however, I think that religious practices are much more than just tools for achieving experiences which would make human life more pleasant.

Dr hab. RoBert T. PTASZEK, prof. KUL - Katolicki Uniwersytet Lubelski Jana Pawła II, Wydział Filozofii, Instytut Filozofii, Katedra Filozofii Religii; adres do korespondencji: Al. Racławickie 14, 20-950 Lublin; e-mail: rptaszek@kul.pl; r.t.ptaszek@gmail.com; ORCID: https://orcid.org/ 0000-0001-9418-5517. 
Likewise, a religious doctrine is something more than a collection of beautiful stories. The reason behind it is my assumption that human beings (which are beings capable of rational thinking), when it comes to choosing a particular religious path, with its particular view of the human being, the world, and the meaning of life, should give attention to ensuring that such views are true, or at least credible.

Until now the issue of truth of religious doctrines has been predominantly the domain of theological dispute. This kind of research in religion, however, has been raising serious questions. The main of them are as follows:

1. Theoretical argument: theology does not look at the divine revelation from a neutral point of view. It is but an interpretation of a revelation the trueness of which is unverifiable.

2. Argument of praxis: if representatives of a church criticize other religious communities, it is likely because their goal is to discredit those groups, and eventually to eliminate them from 'the market of religious services.'

Philosophy, on the other hand, limits itself to mere rational inquiries. It does not refer to revealed truths, and does not proclaim any particular religious concept of salvation. Owing to this, a philosopher is able to carry out research into doctrinal aspects of religions and religious movements without running the risk of raising objections similar to those held against theologians.

Of course, not every path of cultivating philosophy allows for conducting such studies. In my view, it is classical philosophy that provides the best platform for explanation and understanding of the phenomena of new religions and new religiosity. And by classical philosophy I mean the realistic philosophy of being. ${ }^{1}$ For while most of the currents of contemporary philosophy are concerned with - and in fact limited to - analyses of consciousness data or considerations of the language used by people to communicate, classical philosophy makes the object of its inquiries the entire and really existing world of persons and things.

\footnotetext{
${ }^{1}$ This way of philosophising has also been called 'Thomism,' 'neo-Thomism' or 'realistic philosophy.' Its main goal is to answer the question about constitutive factors of the existing reality that make it such as it really is. This philosophical current has roots that go back to ancient Greece, and to the achievements of such philosophers as Aristotle and St. Thomas Aquinas. In Poland it has been creatively developed since the mid- $20^{\text {th }}$ century by the so-called Lublin Philosophical School. See: Mieczysław A. KrĄPIEC and Andrzej MARYNIARCZYK, The Lublin Philosophical School (Lublin: Polskie Towarzystwo Tomasza z Akwinu, 2010); Andrzej MARYNIARCZYK, The Realistic Interpretation of Reality (Lublin: Polskie Towarzystwo Tomasza z Akwinu, 2015); IDEM, Rationality and Finality of the World of Persons and Things (Lublin: Polskie Towarzystwo Tomasza z Akwinu 2016).
} 
Particular relevance of classical philosophy for the purpose of studying the doctrines of religious movements dwells upon the fact that this philosophy takes into consideration a variety of aspects of reality, including those which transcend empirical knowledge. As a result, an integral and holistic vision of man and God - the two key elements of religious relationship becomes achievable on purely rational plane. Realistic philosophy, by virtue of that vision, turns into an efficient tool for showing what concepts of man, God, and the relation between them are contained in the doctrines of alternative religious movements. This philosophy, therefore, has at its disposal a set of proper intellectual tools and procedures not only for description, but also for a rational and critical valuation of doctrinal content of those movements.

This article aims to demonstrate what can be established in terms of the trueness of a religious doctrine, using realistic philosophy of religion. Of course, I do not claim that there are procedures of philosophical reasoning capable of settling the issue of the trueness of a religion once and for all. As Prof. Piotr Moskal has rightly pointed out:

recognizing the trueness of particular religion ... is not a scientific (or philosophical) procedure but a diagnostic and investigative one. It is similar to visit to a medical consultation. The physician, backed by his or her medical expertise and experience, gives the patient his or her diagnosis. This action, although requires knowledge of medical sciences, is not, in itself, a scientific or science-producing action (which does not mean that the data acquired through this medical examination and the diagnosis itself cannot become objects of scientific inquiry). ${ }^{2}$

I intend to demonstrate how philosophy of religion can be successfully applied in order to obtain a preliminary verification of the veracity claim of the doctrine of a particular religious community. In my view, despite difficulties arising mainly from the specific character of the religious language, ${ }^{3}$ "a researcher, when speaking of religious truths, is able to achieve

\footnotetext{
${ }^{2}$ Piotr MosKal, "Zagadnienie rozpoznania religii prawdziwej [The Problem of Recognizing the True Religion]," Roczniki Filozoficzne 58 (2010), 1: 176. Moskal has also expressly pointed out the main shortcoming of philosophical approach to the study of religious doctrines. With philosophy alone "one cannot justify the veracity of what is cognised purely through faith." IDEM, Traktat o religiii [The Treatise on Religion] (Lublin: Wydawnictwo KUL, 2014), 219.

${ }^{3}$ Every religious doctrine contains such truths that cannot be expressed in an exact manner through spoken language. Thus, they cannot become the proper object of philosophical analyses. This specificity of the religious language, however, undermines first of all the feasibility of applying analytical philosophy of language to the issue of the veracity of religious doctrines. Surprisingly, that kind of philosophical approach to the field of the study of religion is currently dominant.
} 
objectivism at least in some aspects, e.g., in confirming their inner consistency or proving their incompatibility with scientific data". This means that the object of philosophical studies of religious doctrines is not as much their veracity in the strict sense as their rational side in general. ${ }^{5}$ The question which rises at this point is how the rationality of a religious doctrine is here understood, and what the methods that would ensure its verification are.

In my studies I adopt the definition of the rational character of a religion formulated by Prof. Andrzej Bronk in his work Podstawy nauk o religii [Foundations of the Study of Religion(s)]: "a religion is rational when its propositions (the so-called truths of faith) are reasonable and true, i.e., they refer to a transcendent world that actually exists, and, on top of that, they are non-contradictory and make up a consistent system of statements". ${ }^{6}$ Having determined the rational character of a religion in such terms, the investigation must begin with establishing whether the doctrine in question is noncontradictory. First, the inner non-contradiction of the doctrine (the condition of being consistent) has to be investigated. The next step is about noncontradiction of the 'outer' kind: one has to determine whether the doctrine contains anything that contradicts the understanding of the world provided by the particular sciences and the realistic philosophy of being. If those two conditions are not met, one has to evaluate the aspirations of a religious movement to the status of a rational religion negatively.

Thus, the issue of non-contradiction is the first one to be studied in philosophical approach to a religion. This issue will be dealt with in this article. By reconstructing and analysing the doctrine of a particular religious movement I want to show how philosophy can help establish that this doctrine does not meet such a criterion. I chose the Church of Jesus Christ of Latter-day Saints (called the Mormon Church for short, or LDS Church), as I find it particularly interesting among the Bible-based, new religious movements-mostly due to the content of their religious texts which will be discussed here shortly.

Suffice it to mention how broad is the interest in the works of the prominent representatives of this current such as Anthony Flew, John Hick, Ian Th. Ramsey, and Alvin Plantinga.

${ }^{4}$ Andrzej Bronk, Podstawy nauk o religii [Foundations of the Study of Religion(s)] (Lublin: Towarzystwo Naukowe KUL, 2003), 339.

${ }^{5}$ But, as Piotr Moskal emphasizes: "The truthfulness of some propositions of the dogmatic and moral doctrine ... can be justified on the basis of solely human cognitive abilities." Piotr MosKAL, Apology for the Catholic Religion (Lublin: Wydawnictwo KUL, 2015), 15.

${ }^{6}$ BRONK, Podstawy nauk o religii, 375. Bronk elucidated this issue from a wider perspective in his article: Andrzej Bronk, "Teologia i nauki przyrodnicze. (Uwagi na marginesie) [Theology and Natural Sciences: (Remarks in the Margins)]," Roczniki Filozoficzne 39/40 (1991/1992), 2: 5-38. 
Concluding this part, I have to declare one more important thing. In my view, a critical approach to religions and religious movements will not make much sense, if we accept the assumption - actually quite popular across the postmodern scientific inquiry and culture - that there is no objective and intelligible truth in the world to be found. For if this assumption is valid, the only studies we can carry out with regard to religious movements will be those that treat them as social groups of a specific kind, meaning the kind that is meant to satisfy some subjectively held and mostly emotional needs deemed important by certain human types. This sociological reductionism turns its back on what is specific to these movements, which is their common aspiration to an entirely different and higher status than that of a social group. In fact, they are laying claims to be new religions which require doctrines to be proclaimed, and their rational premises to be formulated for people to make their minds and join. This is why - as I have already said philosophical analysis of the doctrine, as well as the rational evaluation of its content, are essential for the overall assessment of these religious movement.

\section{WHY MORMONS?}

Mormons are one of the more significant religious movements whose doctrine has biblical ties. Among currently active religious movements the Church of Jesus Christ of Latter-day Saints stands out in several respects:

1. Uses a variety of sources of revelation (the Bible, Book of Mormon, 'living prophets').

2. Tells a story spanning several centuries and covering a big portion of the world - a story which, although originates in the land of Israel, takes place mainly on American soil.

3. Introduces a vision of salvation which is different in many respects from the concepts of other Bible-based religious communities.

4. Claims to be the only true Christian church that continues the work of the church that was founded by Jesus Christ. This is accompanied by the claim of being charged with the mission of reinstating the true Christian church, revealed by Christ himself to the founder of the community, Joseph Smith.

Before I move to the reconstruction and philosophical analysis of the doctrine of the Church of Jesus Christ of Latter-day Saints, two important clarifications have to be made: 
This article is not aimed at a critique of the Mormon Church but rather at demonstrating the inconsistent character of its doctrine. For this reason, I refrain from discussing the issues pertaining to how this religious community actually functions.

Since the object of my studies is the doctrine of the Church of Jesus Christ of Latter-day Saints, I limit myself to the analysis of the source materials. I will refer both to the texts that formed the basis of the Mormon doctrine and those which contained its codifications.

Having said that, let us look more closely into the community itself and its doctrine. I will begin with a few key historical facts on the Mormon religious movement and its founder.

\section{WHO ARE MORMONS?}

I limit my presentation to recalling some of the most relevant facts about the Mormons. The founder of the Mormon community, Joseph Smith (18051844), lived in America in times of a great religious and spiritual upheaval that gave birth to a number of new religious communities.

In 1820 , Smith was said to receive a revelation in which he beheld Heavenly Father and His Son, Jesus Christ. This revelation made him realize that all churches of his time are false churches. Joseph Smith took up the task of establishing an entirely new community. And as he was aiming at restoration of the true church of Jesus Christ, his task encompassed no less that re-creation of all structural elements of a church: the revealed texts, the prophets, the apostles, the priesthood, the sacraments, and the temples.

Emphasising links of his church with the first Christians, and accepting the fact that the true church must be legitimised by succession obtained through direct laying on of hands, Smith announced that he and Oliver Cowdery (one of the scribes of Book of Mormon) were baptised by John the Baptist himself, who descended from heaven to conduct the rite of baptism for them. This part of the story forms the basis of Mormons' conviction that they are the only authentic heirs of the Church established by Jesus Christ. This true Church ceased to exist, according to them, as early as $2^{\text {nd }}$ century due to a number of crucial changes and omissions made by the successors to the apostles, who corrupted and effectively abolished what Jesus had meant to be established.

Claiming to be the only true religion and the acceptance of polygamy led to persecution. Joseph Smith himself was a victim to the persecutions, shot 
dead with one of his brothers on June $27^{\text {th }}, 1844$ by an angry crowd gathered around the prison in Carthage, Illinois. After Smith's untimely death Bringham Young (1801-1877) become the leader. To protect Mormons from violent attacks he led them further West, to the Great Salt Lake, earning himself the name of "American Moses". They founded Salt Lake City which initiated growth of the state of Utah. In 1851 Young became its governor. Salt Lake City has been ever since the world centre of the Mormon Church and the movement itself has spread across the globe.

\section{THE BOOK OF MORMON-}

\section{THE MAIN SOURCE OF THE DOCTRINE}

Joseph Smith wrote down the content of his revelations in Book of Mormon, Doctrine and Covenants ${ }^{7}$ and Pearl of Great Price. ${ }^{8}$ Those books, together with the Bible, are the sources of the Mormon doctrine. ${ }^{9}$ But not only them: the story has never stopped being shaped and developed due to the string of incoming new revelations allegedly provided by God to the Mormon Church through his chosen intermediaries: 'the living prophets.'

Among the scriptures venerated by Mormons Book of Mormon is particularly important. It is also called by the name of The Gospel of $19^{\text {th }}$ Century, as it is supposed to contain 'the fullness of the gospel of Jesus Christ to the Gentiles and to the Jews also. ${ }^{10}$ According to Joseph Smith this book was written as a result of translation of a text engraved on golden plates dug down on Hill Cumorah, upstate New York. The exact spot where the plates had been hidden was revealed to Smith by a heavenly being, angel Moroni. What were written down on those plates were hieroglyphs of the language referred to by Smith as 'reformed Egyptian'. This language remains unknown to linguists as well as Egyptologists; however the Mormon researchers never stopped trying to justify the possibility of its existence. Language is not my subject of research so just mention this problematic issue.

\footnotetext{
${ }^{7}$ It contains 138 revelations of God, mostly directed to Joseph Smith. Those revelations concern a variety of issues: from administrative question (such as the age of children to be baptised, or details of how the Church is to be managed and governed) to eschatological prophecies.

${ }^{8}$ It contains, inter alia, the story of Joseph Smith's life and a Mormon profession of faith in 13 articles.

${ }^{9}$ According to Article 8 of the Basic Points of Belief, Bible is the word of God 'as far as it is translated correctly'. And what is approved as the correct translation, besides the books translated by Smith, is the King James Version of 1611.

${ }^{10}$ Doctrine and Covenants, $20: 9$.
} 
Translation of the text was possible thanks to two crystals, Urim and Thumim, dug out by Joseph Smith. Those artefacts, when held close to his eyes, enabled him to understand the meaning of hieroglyphs he was looking at. And so, in February 1829 Smith commenced the task of translation of the plates, with the resulting story published in print on $26^{\text {th }}$ of March 1830 .

Book of Mormon is divided into 15 parts named after their authors. However, from its content transpires the fact that there were two people responsible for its current shape and form: prophet Mormon and his son Moroni. "The longest portion ... is a translation of Mormon's abridgment of the large plates of Nephi. The concluding portion ... was engraved by Mormon's son Moroni, who, after finishing the record of his father's life, made an abridgment of the Jaredite record (as the Book of Ether) and later added the parts known as the Book of Moroni." a reconstruction and recapitulation of the revelation written down by authors from remote past.

The Book tells the story of the tribes of Israel who have reached the shores of America. It begins with the life of prophet Lehi of Jerusalem (not mentioned in the Bible) who was forced to leave the holy city due to persecution from the Jews. Those events took place during the reign of Zedekiah, before the destruction of the city by Nebuchadnezzar's army. By direct order of God Lehi built a ship, boarded it with his sons, and twenty centuries before Columbus sailed to America. His travel was a success thanks to the use of compass ('Liahona'12) given to him by God.

Conflicts between Lehi's sons have divided the newcomers into wicked Lamanites and righteous Nephites. The story refers also to Jeredites ${ }^{13}$, who had arrived there long before Lehi's family, but the only tribe that eventually survived on the continent were Lamanites. According to Mormons the native American population are their direct descendants. Moroni, son of the prophet Mormon, being the last of the Nephites hid the plates with the engraved Book of Mormon on Hill Cumorah. The story spans over eight centuries between year 600 B.C. and A.D. 421.

${ }^{11}$ A Brief Explanation about the Book of Mormon, The Church of Jesus Christ of Latter Days Saints, accessed 8 December 2018, https://www.lds.org/scriptures/bofm/explanation?lang=eng.

12 "And now, my son, I have somewhat to say concerning the thing which our fathers call a ball, or director - or our fathers called it Liahona, which is, being interpreted, a compass; and the Lord prepared it". Book of Alma, 37:38. Liahona worked according to faith and diligence, Alma 37:40.

${ }^{13}$ History of this tribe is told in only one part of the Book of Mormon, named the Book of Ether. It appears that the Jereds abandoned the gathering of builders of the tower of Babel and sailed to America ca. 2200 B.C. By 600 B.C. they become extinct as a result of wars. 
The Book also contains the account of Christ's visit to America, which allegedly took place after his ascension accounted for in the Bible ${ }^{14}$ :

In the ending of the thirty and fourth year, behold, I will show unto you that the people of Nephi who were spared, and also those who had been called Lamanites, who had been spared, did have great favours shown unto them, and great blessings poured out upon their heads, insomuch that soon after the ascension of Christ into heaven he did truly manifest himself unto them. Showing his body unto them, and ministering unto them. ${ }^{15}$

According to this passage, Jesus appointed during that visit to America another 12 disciples, gave a sermon quite similar to the Sermon on the Mountain, established the sacrament of bread and wine, and predicted future events (speaking, among other things, about his second coming to Earth). After that he left for heaven.

\section{THE KEY COMPONENTS OF THE MORMON DOCTRINE}

To understand and evaluate the Mormon doctrine we have to shed light on three concepts - or visions - it was built upon, namely those of the world, God and man. I am confined to presenting the most controversial Mormon ideas.

\section{THE WORLD}

Mormons assume that the world is God's creation. The accounts of creation of the world given by different Mormon sources vary, and therefore at this point I would like to limit myself to the content of Book of Mormon. It is stated clearly there that the world has been created by God through Jesus as his intermediary. It is particularly stressed in the Third Book of Nephi: "Behold, I am Jesus Christ the Son of God. I created the heavens and the earth, and all things that in them are. I was with the Father from the beginning" ${ }^{\prime \prime}$.

What is important is that Jesus' activities were not limited to creating the one inhabited world which we, humans, live in. "Jesus Christ created this world and everything in it. He also created many other worlds. ... By him, and through him, and of him, the worlds are and were created, and the inhabitants thereof are begotten sons and daughters unto God." ${ }^{17}$

\footnotetext{
${ }^{14} 3$ Nephi, chapters 11 to 28 .

${ }^{15} 3$ Nephi, 10:18-19.

${ }^{16} 3$ Nephi, $9: 15$.

${ }^{17}$ Gospel Principles, 23.
} 
Another issue that is clear beyond any doubt and stated above any differences occurring between particular accounts of creation is the age of the world. The Earth's entire history is limited to only 7,000 years. This means that when we take into account the one-thousand-year rule of Jesus at the end of human history, the world we live in is estimated by Mormons to be little less than 6,000 years old. This opinion is grounded in the revelation received by Joseph Smith "concerning this earth during the seven thousand years of its continuance, or its temporal existence" ${ }^{18}$.

\section{MAN}

Although Mormons refer to the biblical account of creation their vision of man differs in a few substantive ways from other Bible-based anthropologies. First of all, they believe that the primordial rebellion of people against God was indispensable. If not for this the first parents would forever stay in Paradise, enjoying their innocence and not having any children. Adam and Eve falling from grace was therefore a part of God's plan. It paved the way for other people to come to this world, and among them for those who made self-perfection and journeying on towards God the main goal of their lives.

Mormons accept the biblical message about human person being the image and likeness of God. But this likeness is understood quite literally: "This body, which ye now behold, is the body of my spirit; and man have I created after the body of my spirit."19 Such an understanding of 'being a likeness of God' can be found in the official declaration of the Mormon Church titled The Family: A Proclamation to the World.$^{20}$ It states that "ALL HUMAN BEINGSmale and female - are created in the image of God. Each is a beloved spirit son or daughter of heavenly parents, and, as such, each has a divine nature and destiny." 21 Any interpretation respecting basic conformity with the source must infer from this a surprising conclusion that God Creator has to have a spouse. Only by introducing such a twist one can understand the importance of 'marriage for eternity' and the ultimate goal of the Mormon path to salvation. This path, called 'the plan of eternal progress' will be discussed further on in this presentation.

\footnotetext{
${ }^{18}$ Doctrine and Covenants, $77: 6$.

${ }^{19}$ Ether, $3: 16$.

${ }^{20}$ The Proclamation is accessible at the page of The Church of Jesus Christ of Latter Days Saints, accessed 10 December 2018, www.lds.org/topics/family-proclamation?lang=eng\&old= true.

${ }^{21}$ The Family: A Proclamation to the World, ibidem.
} 
Mormons believe that people live 'pre-mortal' lives as spiritual beings before they are born on Earth. ${ }^{22}$ This first, heavenly stage of life is the time of preparation of talents and individual qualities necessary for fulfilment of the personal mission on Earth. "IN THE PREMORTAL REALM, spirit sons and daughters knew and worshipped God as their Eternal Father and accepted His plan by which His children could obtain a physical body and gain earthly experience to progress toward perfection and ultimately realize their divine destiny as heirs of eternal life." 23

There are more views and statements on man that are equally controversial. Mormons believe that people can become angels, and bear witness to the results of such a transformation in Moroni, son of prophet Mormon. In his earthly life he was a man, but he revealed himself to Joseph Smith as an angel. His sculpture on the top of the tower of the Mormon temple in Salt Lake City presents him in his angelic state. But it is also possible to go the other way round. Adam, the first of men, before he received his body and began his earthly life, was - according to Mormons-Michael the Archangel, and was in command during a battle against the forces of Satan. ${ }^{24}$

The basic views of man here demonstrated clearly show that Mormon doctrine, although expressed in terms derived from biblical sources, is quite disconnected with the contents of biblical revelation. The same applies to the Mormon conception of God.

\section{GOD}

The first of the Basic Points of Belief says: "We believe in God, the Eternal Father, and in His Son, Jesus Christ, and in the Holy Ghost." 25 Such wording suggests that Mormons profess a Trinitarian faith (one God in three persons). But a closer analysis of their texts shows that those three mentioned are quite separate from one another. Mormon teaching on relationship between the Father, Jesus Christ and the Holy Spirit is vaguely expressed. In the Second Book of Nephi it says: "This is the doctrine of Christ, and the only and true doctrine of the Father, and of the Son, and of the Holy Ghost, which is one God, without end." ${ }^{26}$ But according to the Doctrine and Cove-

${ }^{22}$ See, as an example, Doctrine and Covenants, $93: 29$.

${ }^{23}$ The Family: A Proclamation to the World, see above.

${ }^{24}$ See: Gospel Principles, 29.

${ }^{25}$ The Articles of Faith of The Church of Jesus Christ of Latter-day Saints, The Church of Jesus Christ of Latter Days Saints, accessed 12 December 2018, https://www.lds.org/scriptures/pgp/a-of$\mathrm{f} / 1$ ?lang=eng .

${ }^{26} 2$ Nephi, 31:21. 
nants, "The Father has a body of flesh and bones as tangible as man's; the Son also; but the Holy Ghost has not a body of flesh and bones, but is a personage of Spirit. Were it not so, the Holy Ghost could not dwell in us."27

Those two passages demonstrate what kind of difficulties arise if we look for a coherent conception of God in the Mormon main sources. Among the texts recognised as parts of the revelation there are some that suggest that God is conceived as spiritual in nature, and of one and unchanging nature "unchangeable from all eternity to all eternity." ${ }^{28}$ Other texts, however, represent God as a material entity: "And the veil was taken from off the eyes of the brother of Jared, and he saw the finger of the Lord; and it was as the finger of a man, like unto flesh and blood" ${ }^{\prime 29}$. Furthermore, the dwelling place of God and his angels is depicted as a surface of a planet: "a globe like a sea of glass and fire." 30

The essence of the Mormon conception of God was expressed in the famous saying by Joseph Smith:

God himself was once as we are now, and is an exalted man, and sits enthroned in yonder heavens! That is the great secret. If the veil were rent today, and the great God who holds this world in its orbit, and who upholds all worlds and all things by his power, was to make himself visible, - I say, if you were to see him today, you would see him like a man in form - like yourselves in all the person, image, and very form as a man. ${ }^{31}$

It can therefore be concluded that God of Mormons, being a material entity that constantly develops and perfects itself is not even remotely related to the spiritual fullness of perfection known from the Bible.

There are deficits of coherence and clarity with regard to the person of Jesus as well. In the passages of Book of Mormon presenting his stay in America he speaks about himself "I am the God of Israel, and the God of the whole earth, and have been slain for the sins of the world." ${ }^{32}$ But other Mormon texts characterise him as mere the first (the eldest) son of God (with other texts suggesting that there was a second son after him, namely Lucifer ${ }^{33}$ ). And

${ }^{27}$ Doctrine and Covenants, 130:22.

${ }^{28}$ Moroni, 8:18.

${ }^{29}$ Ether, $3: 6$.

${ }^{30}$ Doctrine and Covenants, 130:7.

${ }^{31}$ Teachings of the Prophet Joseph Smith, 345.

32 Nephi, 11:14.

33 "We needed a Savior to pay for our sins ... Jesus Christ who was called Jehovah, said, 'Here am I, send me' ... Satan, who was called Lucifer, also came, saying, 'Behold, here am I, send me'.” Gospel Principles, 15. 
if we follow that thought Jesus would appear to be only one of many 'gods' that are active in this world. On the other hand one has to doubt the appropriateness of such an interpretation in the light of the fact that there are texts in which Jesus is openly identified with $\operatorname{God}^{34}$. The official declaration of the Mormon Church, titled The Living Christ is not entirely clear in this matter $^{35}$. The statements there contained tend to blur the picture rather than explicate the views of the Church with regard to the nature of Christ:

He was the Great Jehovah of the Old Testament, the Messiah of the New. Under the direction of His Father, He was the creator of the earth. ... He was the Firstborn of the Father, the Only Begotten Son in the flesh, the Redeemer of the world. ... That by him, and through him, and of him, the worlds are and were created, and the inhabitants thereof are begotten sons and daughters unto God. ${ }^{36}$

The vagueness of this declaration opens it to a range of interpretations of the person of Jesus Christ.

The Holy Spirit is recognized by Mormons as a "member of the Trinity," but the way this divine person is conceptualized is very far from the image upheld by mainstream Christian churches. Relatively minor differences concern functions performed by this divine person. What is unprecedented, however, is the Mormon view of his nature and a specific manner in which He operates. According to them "He is a 'personage of Spirit.' ... He can be in only one place at a time, but His influence can be everywhere at the same time." ${ }^{37}$

Having finished all the above clarifications we can move to discuss the main points of the doctrine.

\section{HOLY LAND AND THE VISION OF SALVATION}

Mormon doctrine is a story about the path leading human beings to salvation. This salvific process will be accomplished in two stages.

\footnotetext{
${ }^{34}$ It is so, among others, in the Book of Ether: "I am he who was prepared from the foundation of the world to redeem my people. Behold, I am Jesus Christ. I am the Father and the Son. In me shall all mankind have life, and that eternally, even they who shall believe on my name; and they shall become my sons and my daughters" (Ether, $3: 14)$.

${ }^{35}$ The Living Christ: The Testimony of the Apostles, The Church of Jesus Christ of Latter-day Saints, The Church of Jesus Christ of Latter Days Saints, accessed 13 December 2018 , https://www.lds.org/liahona/2000/04/the-living-christ-the-testimony-of-the-apostles-the-church-ofjesus-christ-of-latter-day-saints?lang=eng.

${ }^{36}$ Ibidem.

${ }^{37}$ Gospel Principles, 33.
} 


\section{Holy Land - the Millennium}

Mormons are a millenarian community. They expect a thousand-year kingdom before the world would eventually come to an end. This kingdom will be established on this Earth (which makes their position a chiliastic one, to be exact ${ }^{38}$ ), and the city of God, the New Jerusalem, will be erected in North America. There is a prophecy on this given by God to Joseph Smith:

the Lord your God, who have assembled yourselves together, according to my commandments, in this land, which is the land of Missouri, which is the land which I have appointed and consecrated for the gathering of the saints. Wherefore, this is the land of promise, and the place for the city of Zion. And thus saith the Lord your God, if you will receive wisdom here is wisdom. Behold, the place which is now called Independence is the centre place ${ }^{39}$.

And because the Garden of Eden (or the Paradise) was situated, according to Mormons, in the state of Missouri ${ }^{40}$ the history of the world would thus complete a full circle: "The earth will be renewed and receive its paradisiacal glory" 41 .

During the thousand-year rule of Christ, referred to by Mormons as 'the Millenium' there will be no wars. They also state that

The Lord will be king over all the earth, and all mankind literally under his sovereignty, and every nation under the heavens will have to acknowledge his authority, and bow to his scepter. Those who serve him in righteousness will have communications with God, and with Jesus; ... For it will be the reign of God upon the earth, and he will enforce his laws, and command that obedience from the nations of the world which is legitimately his right. ${ }^{42}$

The main task that Mormons will stand before during the Millennium will be to baptise all humankind. The reason for this is the belief that the necessary condition for salvation is to receive a valid (meaning: Mormon) baptism.

At the end of the Millennium the devil will be released for a short period of time. He will challenge the heavenly armies commanded by Archangel Michael. As a result of the ensuing final battle "the devil and his armies

${ }^{38}$ According to chiliastic conception, the kingdom of Christ will be established on Earth, while millenarian conception speaks about Christ reigning with the righteous in Heaven.

${ }^{39}$ Doctrine and Covenants, 57:1-4.

${ }^{40}$ Sandra TANNER, "Was The Garden of Eden in Missouri?," Utah Lighthouse Ministry, Online Resources, accessed 8 December 2018, http://www.utlm.org/onlineresources/gardenofeden.htm.

${ }^{41}$ Gospel Principles, 265.

${ }^{42}$ Ibidem, 266. 
shall be cast away into their own place, that they shall not have power over the saints any more at all." ${ }^{, 3}$. After the battle the last judgement will commence. And what ultimate destiny is reserved for humans - that is the topic best explained by the plan of eternal progress.

\section{VISION OF SALVATION-THE PLAN OF ETERNAL PROGRESS}

Mormon doctrine provides a detailed vision of human destinies after death. The period of earthly existence is, according to them, the time of trial. The plan of eternal progress assumes that people will be allocated to respective kingdoms by virtue of what they have accomplished during their earthly lives.

At the last judgement people will be divided into three groups. Each of them will be granted a "different place in heaven" and a different reward:

- Mormons, who participated in the first resurrection, will enjoy heavenly existence in the 'celestial sphere.' They "will live with Heavenly Father and Jesus Christ forever" 44 and the glory they will receive will be comparable to the 'glory of the Sun';

- The righteous who during their lifetimes were not, however, the members of the Mormon community, but received the valid baptism after their death (while inhabiting the spirit world) will be bound for earthly zone: "the terrestrial sphere". Their glory will be like the 'glory of the Moon,' and their sphere "will be visited by Jesus Christ but not by our Heavenly Father"45;

- Those that did not receive their baptism in the spirit world and were granted redemption only after the first resurrection will inhabit the underground, 'celestial' sphere, and will share in the 'glory of the stars.' Their sphere will be visited neither by God nor Jesus, but only by the Holy Spirit.

This kind of eschatological division is a further example of the specific, Mormon understanding of Christian Trinity as three different divine entities, subordinate to one another in descending order.

According to Mormons not all the people will be blessed with either of the grades of glory. Those who have learnt the truth about Jesus but later on rejected it anyway will be damned forever:

There is no forgiveness in this world nor in the world to come .... These are they who shall go away into the lake of fire and brimstone, with the devil and his

\footnotetext{
${ }^{43}$ Doctrine and Covenants, 88:114.

${ }^{44}$ Gospel Principles, 272.

${ }^{45}$ Ibidem, 273.
} 
angels. And the only ones on whom the second death shall have any power; Yea, verily, the only ones who shall not be redeemed in the due time of the Lord, after the sufferings of his wrath. ${ }^{46}$

There is also a special reward for those who managed to reach the highest level of perfection in their mortal life. These are the ones who learnt the plan of God, and obeyed his will on Earth. They will ascend to the highest level of celestial kingdom, and thus will have an opportunity to become gods themselves. In Smith's revelations it is said: "They are they who received the testimony of Jesus, and believed on his name and were baptized after the manner of his burial, being buried in the water in his name ... they are gods, even the sons of God." 47 This final achievement available within the frames of the plan of eternal progress is called 'Exaltation.' Mormons believe that human beings - at least some of them - are destined to become gods and populate further worlds with their offspring. "They will receive special blessings. ... They will receive a fullness of joy. ... They will have everything that our Heavenly Father and Jesus Christ have-all power, glory, dominion, and knowledge." 48

A small but interesting detail to conclude the matter: the revelation given to Joseph Smith also indicates that animals do have souls that are immortal, and therefore will participate in immortality and eternal happiness ${ }^{49}$.

\section{CONCLUDING REMARKS}

As a philosopher and a person who studied the doctrine of Mormons I want to highlight three concluding issues:

1. Analyses presented here were all as general and preliminary as they could be, and still they reveal a number of weak points, inconsistencies and oversimplifications embedded in the doctrine. Some of its elements (such as the American episode of Christ's mission or the vision of the New Jerusalem to be erected on American soil) are downright naive. But there are others, many of them not mentioned here, such as the U-turn on polygamy issue, which demonstrate that the same doctrine happens to be treated merely as a tool for securing goals that are far beyond its scope.

\footnotetext{
${ }^{46}$ Doctrine and Covenants, 76:34-38.

${ }^{47}$ Ibidem, $76: 51$ and 58.

${ }^{48}$ Gospel Principles, 278.

${ }^{49}$ See Doctrine and Covenants, $77: 1-4$.
} 
2. Theoretical incoherence of this religious doctrine sets up an intellectual riddle, which is this: These inconsistencies and statements did not affect or disturb in any way the faith of the members of the Mormon Church, who are just as educated and rational people as anybody else.

To solve this riddle, in my opinion, the Church of Jesus Christ of Latterday Saints has to be looked at from a broader perspective, involving not only the doctrine that is being proclaimed there but also the Mormon way of life. It would modify the whole picture substantially. From that angle one could see a community of people who follow simple and clear-cut rules of conduct, ensuring high ethical standards despite the present-day relativism and axiological chaos. What is more, their genuine care for wholesome family structures would also be clearly visible, as well as their involvement in religious life and missionary activities (Mormon missionaries can be seen virtually across the globe). But this perspective lies outside the scope of our present considerations. Therefore, to summarize them, I can only admit that realistic philosophy of religion falls short of providing a satisfactory answer to the question why Mormons still put their faith in a doctrine that is so inconsistent. A clarification would likely involve some way of demonstrating that concern for the truth, also in the field of religion, is characteristic to that way of approaching reality (and this way of philosophizing) which we call 'realism'. But such a cognitive approach to the world is no longer universally accepted. Especially after the postmodern upheaval at the end of the $20^{\text {th }}$ century more and more people tend to think about themselves and the world around them in terms of relativism and irrationalism. Now, why this is happening is yet another subject-matter far beyond the scope of this article. Here, it has only been demonstrated what consequences arise from similar attitudes entertained in the sphere of religious beliefs.

\section{BIBLIOGRAPHY}

A Brief Explanation about the Book of Mormon. The Church of Jesus Christ of Latter Days Saints. Accessed 8 December 2018. https://www.lds.org/scriptures/bofm/ explanation?lang= eng.

Book of Mormon. Another Testament of Jesus Christ. The Church of Jesus Christ of Latter Days Saints. Accessed 6 December 2018. https://www.lds.org/scriptures/bofm?lang=eng.

Bronk, Andrzej. Podstawy nauk o religii [Foundations of the Study of Religion(s)]. Lublin: Towarzystwo Naukowe KUL, 2003.

BRONK, Andrzej. "Teologia i nauki przyrodnicze. (Uwagi na marginesie) [Theology and Natural Sciences. (Remarks in the Margins)]." Roczniki Filozoficzne 39/40 (1991/1992), 2: 5-38. 
Doctrine and Covenants of The Church of Jesus Christ of Latter-day Saints. The Church of Jesus Christ of Latter Days Saints. Accessed 6 December 2018. https://www.lds.org/scriptures/ dc-testament?lang=eng.

Gospel Principles. The Church of Jesus Christ of Latter Days Saints. Accessed 10 December 2018. https://www.lds.org/manual/gospel-principles?lang=eng.

KrĄPIEC, Mieczysław Albert, and Andrzej MARYNIARCZYK. The Lublin Philosophical School. Lublin: Polskie Towarzystwo Tomasza z Akwinu, 2010.

MARYNIARCZYK, Andrzej. Rationality and Finality of the World of Persons and Things. Lublin: Polskie Towarzystwo Tomasza z Akwinu, 2016.

MARYNIARCZYK, Andrzej. The Realistic Interpretation of Reality. Lublin: Polskie Towarzystwo Tomasza z Akwinu, 2015.

Moskal, Piotr. Apology for the Catholic Religion. Lublin: Wydawnictwo KUL, 2013.

Moskal, Piotr. Traktat o religii [The Treatise on Religion]. Lublin: Wydawnictwo KUL, 2014.

Moskal, Piotr. "Zagadnienie rozpoznania religii prawdziwej [The Problem of Recognizing the True Religion]." Roczniki Filozoficzne 58 (2010), 1: 175-185.

Pearl of Great Price. The Church of Jesus Christ of Latter Days Saints. Accessed 6 December 2018. https://www.lds.org/scriptures/pgp?lang=eng.

TANNER, Sandra. "Was The Garden of Eden in Missouri?" Utah Lighthouse Ministry, Online Resources. Accessed 8 December 2018. http://www.utlm.org/onlineresources/ gardenofeden.htm.

Teachings of the Prophet Joseph Smith. The Church of Jesus Christ of Latter Days Saints. Accessed 12 December 2018. https://www.lds.org/manual/teachings-joseph-smith?lang= eng.

The Articles of Faith of The Church of Jesus Christ of Latter-day Saints. The Church of Jesus Christ of Latter Days Saints. Accessed 12 December 2018. https://www.lds.org/scriptures/ pgp/a-of-f/1?lang=eng.

The Family: A Proclamation to the World. The Church of Jesus Christ of Latter Days Saints. Accessed 10 December 2018. https://www.lds.org/topics/family-proclamation?lang=eng\& old $=$ true.

The Living Christ: The Testimony of the Apostles, The Church of Jesus Christ of Latter-day Saints. The Church of Jesus Christ of Latter Days Saints. Accessed 13 December 2018. https://www.lds.org/liahona/2000/04/the-living-christ-the-testimony-of-the-apostles-thechurch- of-jesus-christ-of-latter-day-saints?lang=eng.

\section{THE CHURCH OF JESUS CHRIST OF LATTER-DAY SAINTS AND ITS DOCTRINE: A PHILOSOPHICAL APPROACH}

\section{Su m mary}

In the article, I demonstrate how realistic philosophy of religion can be employed in order to obtain a preliminary verification of the truthfulness of the doctrine proclaimed by a particular religious community. The first element of a religious doctrine that qualifies for philosophical evaluation is its non-contradictory character. For this reason I endeavour to reconstruct one such doctrine and show how it is possible to demonstrate, through philosophical analyses, that such a doctrine does not meet the aforementioned criterion. For the object of my studies I chose the Church of Jesus Christ of Latter-day Saints (called the Mormon Church for short), as I find it particularly interesting among the religious movements alternative to Christianity.

Among new religious movements currently in existence the Mormon Church stands out in several respects. First, this religious community utilises a variety of sources of revelation. Fur- 
thermore, although their sacred story, that spanning a dozen or so centuries, begins in Israel it mostly takes place on American soil. Finally, the Mormon Church sets forth a vision of a future 'holy land,' and the concept of salvation that is essentially different from those of other Biblebased religious movements.

The Mormon concept of salvation, referred to as the plan of eternal progress shows both unique goal and unique means to achieve it. People are to become gods and populate multiple worlds. According to Mormons there will be different levels of salvation associated with what life a person lived on earth.

Reconstruction and philosophical analysis of the main elements of the Mormon doctrine shows its weak points, inconsistencies, and oversimplifications. From this perspective, the Mormon 'sacred story' hardly could be regarded as something more than a colourful and interesting myth. But the question of reasons why Mormons still put their faith in such an inconsistent doctrine lies outside the scope of these considerations.

\section{KOŚCIÓ£ JEZUSA CHRYSTUSA ŚWIĘTYCH W DNIACH OSTATNICH I JEGO DOKTRYNA Z PERSPEKTYWY FILOZOFII}

\section{Streszczenie}

W artykule pokazuję, jak za pomocą realistycznej filozofii religii można dokonać wstępnej weryfikacji prawdziwościowych aspiracji doktryny konkretnej wspólnoty religijnej. Pierwszym elementem doktryny religijnej możliwym do filozoficznej oceny jest jej niesprzeczność. Dlatego w tekście rekonstruuję doktrynę konkretnego ruchu religijnego i pokazuję, jak na drodze filozoficznych analiz można wykazać, że nie spełnia ona tego kryterium. Jako przedmiot badań wybrałem główne elementy doktryny Kościoła Jezusa Chrystusa Świętych w Dniach Ostatnich (nazywanego w skrócie Kościołem Mormonów), ponieważ uważam go za szczególnie interesujący alternatywny wobec chrześcijaństwa ruch religijny.

Spośród działających obecnie ruchów religijnych Kościół Jezusa Chrystusa Świętych w Dniach Ostatnich wyróżnia się pod kilkoma względami. Przede wszystkim wspólnota ta korzysta z wielu różnych źródeł objawienia. Ponadto ich „święta opowieść” to licząca kilkanaście wieków historia, która choć rozpoczyna się w Izraelu, w większości dzieje się na kontynencie amerykańskim. Wreszcie Kościół Mormonów przedstawia wizję „ziemi świętej” oraz koncepcję zbawienia, które w istotny sposób różną się od koncepcji przyjmowanych przez inne wspólnoty religijne bazujące na Biblii.

Oryginalność koncepcji zbawienia mormonów, którą nazywają „planem wiecznego postępu”, dotyczy zarówno celu tego planu, jak też możliwych form jego realizacji. Jeśli chodzi o cel, to według mormonów ludzie mogą stać się bogami i zaludniać swoim potomstwem kolejne światy.

Przeprowadzona z punktu widzenia filozofii religii rekonstrukcja i analiza głównych elementów doktryny mormonów pokazuje jej liczne słabości, niespójności i uproszczenia. $Z$ tej perspektywy „świętą opowieść" mormonów trudno uznać za coś więcej niż tylko barwny i intersujący mit. Natomiast odpowiedź na pytanie, dlaczego mormoni wciąż wierzą w tak niespójną doktrynę, wykracza poza zakres podjętych w artykule rozważań.

Key words: philosophy of religion; religious doctrines; alternative religious movements; the Church of Jesus Christ of Latter-day Saints.

Słowa kluczowe: filozofia religii, doktryny religijne, alternatywne ruchy religijne, Kościół Jezusa Chrystusa Świętych w Dniach Ostatnich. 
Information about Author: Dr. hab. Robert T. PtaszeK, Prof. at KUL - the John Paul II Catholic University of Lublin, Faculty of Philosophy, Institute of Philosophy, Department of the Philosophy of Religion; address for correspondence: Al. Racławickie 14, 20-950 Lublin, Poland; e-mail: rptaszek@kul.pl; r.t.ptaszek@gmail.com; ORCID: https://orcid.org/0000-00019418-5517. 